\title{
A CRISE DA CIÊNCIA* \\ O REI (NÃO) ESTÁ NU
}

Newton Key Hokama, Paula de Oliveira Montandon Hokama**

\section{PARTE 1: O REI ESTÁ NU}

\author{
Olha lá. \\ Lá vem o Rei (A VERDADE) \\ Ele está nu. \\ O Rei está nu. \\ Mas ainda é Rei. \\ O Rei se veste com roupas de \\ Realeza porque é Rei? \\ Ou a roupa de Realeza só é de \\ Realeza porque é do Rei? \\ O Rei está nu. \\ Mas não perde a Realeza. \\ O Rei é Rei. \\ Mesmo nu. \\ O Rei é mais Rei porque está nu.
}

* Leitura do texto "Um discurso sobre as Ciências na transição para uma ciência pós-moderna", Boaventura Santos, Estudos Avançados, 1988. Trabalho produzido durante as disciplinas pedagógicas do Curso de Pós-Graduação da Faculdade de Medicina da UNESP, campus de Botucatu, 1996.

** Hemocentro de Botucatu / HC, FMB / UNESP 


\title{
PARTE 2: O SUJEITO E O OBJETO
}

\author{
O sujeito e o objeto \\ O sujeito vê o objeto. \\ O sujeito quebra o objeto. \\ o sujeito monta o hobigetho. \\ O sujeito e o objeto \\ O sujeito rodeia o objeto. \\ $\mathrm{O}$ objeto rodeia o sujeito. \\ Vertigens. \\ O sujeito e o objeto. \\ Um passo para trás. \\ Um passo para frente. \\ São dois prá lá, dois prá cá. \\ Q mesmo bolero. \\ O sujeito e o objeto.

\section{Outro sujeito.} \\ O sujeito e o objeto são objeto do outro sujeito \\ Outro sujeito. \\ O sujeito e o sujeito e o objeto são objeto do outro sujeito. \\ Sujeito/Objeto. \\ Objeto/Sujeito \\ Objeto? \\ Sujeito? \\ Estranhezas nessas palavras... \\ Alguém mais pensou nisso? \\ Sim, Jung sonhou. \\ Quem sou senão meus sonhos? \\ Quem sou senão os outros? \\ Sincronicidade \\ Deus? \\ Sim \\ Não \\ Talvez \\ Uma questão de fé.
}




\title{
PARTE 3: O REI (NÃO) ESTÁ NU
}

\section{Epistemologia. Paradigmas. Concepção Pós-Moderna.}

\author{
Transição. \\ Teoria Sinergética. \\ Palavras difíceis ( O que significam? Quem as entende?) \\ Rousseau. Nagel. Reichenbach. Wigner. \\ Estrangeiros \\ (Quem serão? Que língua falarão?)
}

Ah. Finalmente entendo alguma coisa do texto. Diz sobre o senso comum. Valorizá-lo.

Ei, João!!! Ei, José!!! A roda gigante, o domingo, o sorvete é vermelho. A faca e o ciúme.

O sangue é vermelho.

\section{Ei, João!!! Ei, José!!! O que é isso companheiro?}

O que é senso comum????

O que é senso senão o contrário de não-senso comum? Ou será o avesso do senso incomum? Ou o avesso do avesso do avesso do senso (para rimar, apenas, e não a solução)?

Sim, são apenas palavras. Sim, são estrangeiros.

Sim, o texto fala em nome de alguém em transição (nós). Por tudo isso o compreendo, dentro de minha compreensão (eu, metáfora e contradição). 
Conhecimento é auto-conhecimento. Local e total.

Científico Natural e Científico Social.

\title{
Ciência e Arte.
}

\author{
É humano. \\ Tudo é humano. \\ O sujeito e o objeto. \\ Os mitos. \\ De onde eu vim, prá onde eu vou. \\ Os planos.

\begin{abstract}
$O$ vôo das estrelas e das constelações cabem agora no meu papel e são escritos pelo meu lápis. São fórmulas, nada mais do que fórmulas.
\end{abstract}

Depois que naveguei na velocidade da luz, perdi a inocência do tempo perdido. Iluminei.

Depois que mergulhei em busca da profundeza da matéria, não sobrou nada, apenas incertezas. Afundei.

O que era perto ficou longe.

O que era longe era eu.

Quando me achei, me perdi. 